\title{
Miniaturization and 3D Printing of Bioreactors: A Technological Mini Review
}

\author{
Spyridon Achinas *, Jorn-Ids Heins, Janneke Krooneman and Gerrit Jan Willem Euverink \\ Faculty of Science and Engineering, University of Groningen, 9747 AG Groningen, The Netherlands; \\ j.i.heins@student.rug.nl (J.-I.H.); j.krooneman@rug.nl (J.K.); g.j.w.euverink@rug.nl (G.J.W.E.) \\ * Correspondence: s.achinas@rug.nl
}

Received: 10 August 2020; Accepted: 10 September 2020; Published: 14 September 2020

\begin{abstract}
Many articles have been published on scale-down concepts as well as additive manufacturing techniques. However, information is scarce when miniaturization and 3D printing are applied in the fabrication of bioreactor systems. Therefore, garnering information for the interfaces between miniaturization and 3D printing becomes important and essential. The first goal is to examine the miniaturization aspects concerning bioreactor screening systems. The second goal is to review successful modalities of 3D printing and its applications in bioreactor manufacturing. This paper intends to provide information on anaerobic digestion process intensification by fusion of miniaturization technique and 3D printing technology. In particular, it gives a perspective on the challenges of $3 \mathrm{D}$ printing and the options of miniature bioreactor systems for process high-throughput screening.
\end{abstract}

Keywords: miniaturization; 3D printing; bioreactors; materials; process intensification

\section{Introduction}

The pressure to reduce bioreactor costs and accelerate the bioprocess development in the biotech industry is ongoing and increasing [1]. The identification of optimal parameters for new biotechnological processes is a costly and time-consuming part of the development process, due to the multiple settings [2]. Since optimizing process conditions at a manufacturing scale are not practical and efficient, the development of miniaturized models that represent the performance of the industrial process is essential to achieve reliable process characterization [3]. Thus, parametric optimization through process screening is urgently needed for bioprocess development [2]. Miniature bioreactors are useful as such a process screening method, where multiple formulations or conditions are screened to identify the optimal set of values [4]. Notably, the integration of engineering and biological principles is essential for the scaling-down of bioreactors [5].

Similar to reactor performance in chemical research, in biochemical research, the term bioreactor performance is often used. However, a rapid scan of the literature elucidated that bioreactor performance is a well-known known concept, but it is never thoroughly explained [6,7]. In practice, the performance of a biochemical conversion process, i.e., the bioreactor performance, is mainly determined by the benefit/cost ratio [8]. For optimization purposes, the criteria for a high volume/low value-added product are usually different from criteria used for the low volume/high value-added product. Thus, a bioreactor's performance can be either evaluated by the yield of the desired product on the substrate (g product per $g$ substrate), the productivity (g product per L reactor volume per hour) or the final titer (g product per L reactor volume) [9].

However, process performance usually connects to a particular market price of the product. On the other hand, there are also costs involved in the microbial conversion processes. The reduction of costs is often the main objective of biochemical engineering [8]. The bioreactor vessel is the core 
part of the bioreactor system. Within the bioreactor vessel, the solution is mixed to maintain a homogeneous solution, which affects the optimal performance. Different mixing methods [10,11] are used to obtain the perfect mixing by looking at the fluid flow, mixing rate and mixing time as parameters. Furthermore, the cultivation process needs to be carefully controlled. Sensors for $\mathrm{pH}$, temperature, dissolved oxygen concentration, and foam are necessary to maintain optimal conditions for bacterial growth and/or synthesis of products. Contrary to conventional chemical reactors, bioreactors must provide a higher degree of control over process upsets and prevent contaminations by other microorganisms. These bioreactors are used to grow bacteria in a complex fluidic environment. Before newly found bacteria can be used in biotechnological applications, the bacteria first need to be characterized to determine in which environmental circumstances the bacteria will perform optimally. It is also important to know how the bacteria will react to the different situations that are applied by the operators.

Bioreactors can also be used for the production of cells where batch production is facilitated. The problem is that these batch-wise operated bioreactors have a lower output per volume per hour unit than with continuously operated bioreactors. On the other hand, continuously operated bioreactors have more risk involved, because the impact of the failure is higher. However, if there is a way to reduce the effect of failure in these types of bioreactors, then this can replace the batch-wise operated bioreactor. Lowering the impact of failure can be achieved by spreading the risk. Such an approach implies a system of many continuous bioreactors working independently. Hence, if one or more bioreactor becomes contaminated, it can be shut down, and all other bioreactors remain in operation. The approach in scaling-up by numbers instead of scaling-up by size reduces the risks in fermentation processes but increases the amount of materials needed.

Biotechnological applications can differ significantly from each other. Therefore, a suitable process screening system varies per specific application. A flexible and modular system deals with the variation in applications. The 3D printing process helps to quickly manufacture the particular modules that are necessary for the screening. Additive Manufacturing describes the 3D printing process in a larger whole. The 3D printing is a crucial part of Additive Manufacturing as it enables the construction of the design layer-by-layer rather than through molding or subtractive techniques [12]. Moreover, this technique provides high customizability while producing small quantities at relatively low cost in a short period [13].

This paper combines technological perspectives of fusion of miniaturization and 3D printing for the development of multi-parallel bioreactor screening systems. This paper is a short and comprehensive perspective of 3D printing technologies with a selection of references summarizing research progress and challenges in applying miniature bioreactor systems. It reflects not only on miniaturization concepts but also on 3D printing techniques, as well as on the auxiliary equipment that is part of the screening system.

\section{Miniaturization}

\subsection{Scale-Down Concept}

According to Latterman and Buchs [14], the design of a bioreactor typically varies in shape, material properties and instrumentation, which have a direct influence on the performance. Miniaturization or else scaling-down of bioreactors is a current trend and promising solution for optimization studies in biotechnology (e.g., fermentation, anaerobic digestion) [15,16]. Miniaturization aims at replacing bench-scale bioreactors and ultimately pilot-scale bioreactors (Figure 1) [17]. Unfortunately, the current small-scale lab systems (e.g., shaken flask systems) lack automated feeding, $\mathrm{pH}$ and/or oxygen control, a fact that is unfavorable for developing microbial fermentations [18,19]. Thus, the parallel running miniature system has become a more attractive method as they provide early-stage process understanding during process development [20]. Miniature bioreactors must mimic conditions that microbial communities or pure cultures experience in larger vessels [21,22]. 
Figure 2 depicts important aspects that have to be considered for the optimal bioreactor design. Reliability, cost-efficiency and process performance are the utmost important aspects of bioreactor design, followed by sustainable reengineering (reactor and process redesign) and product innovation.

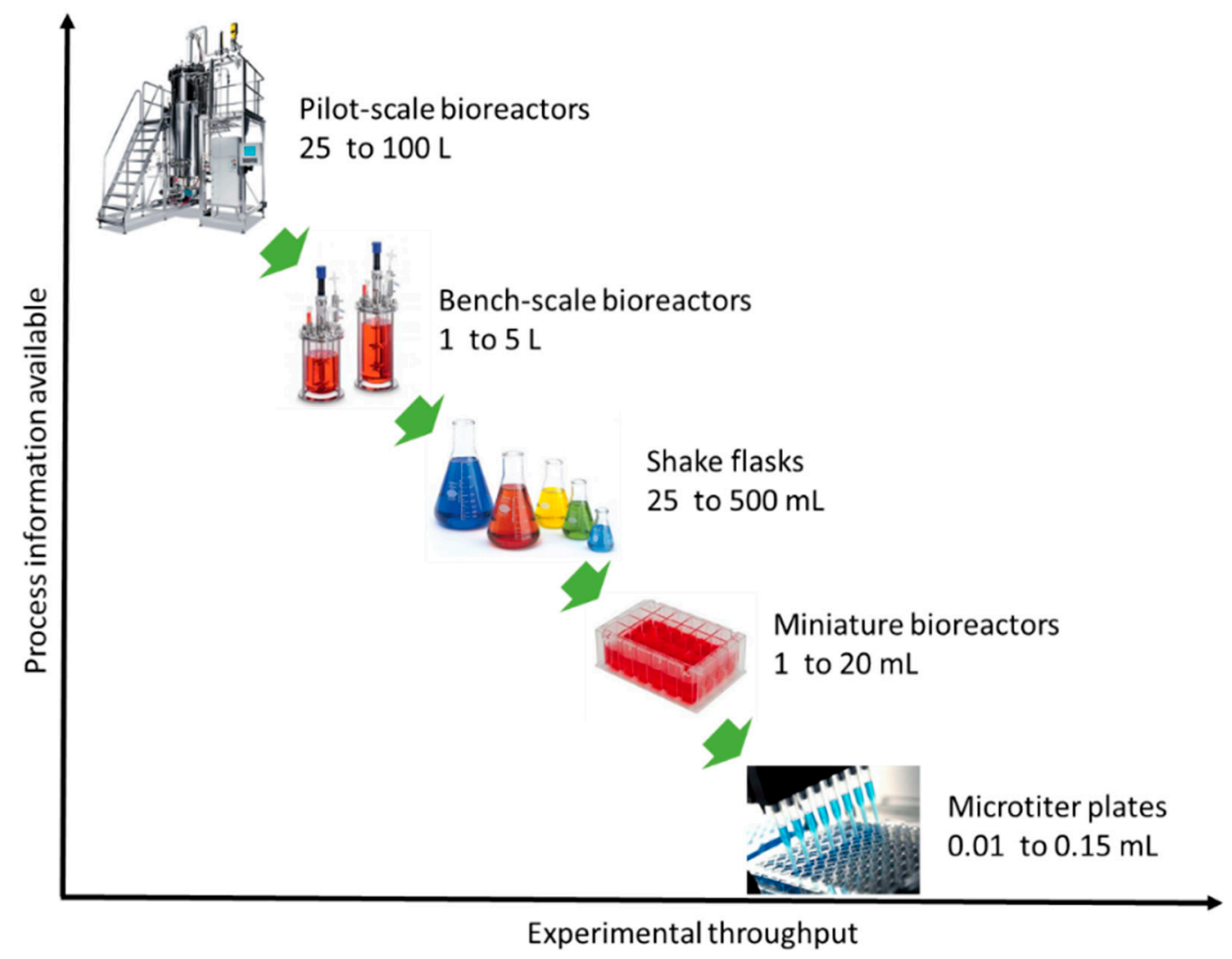

Figure 1. Relation of process information with experimental output for different scale bioreactors.

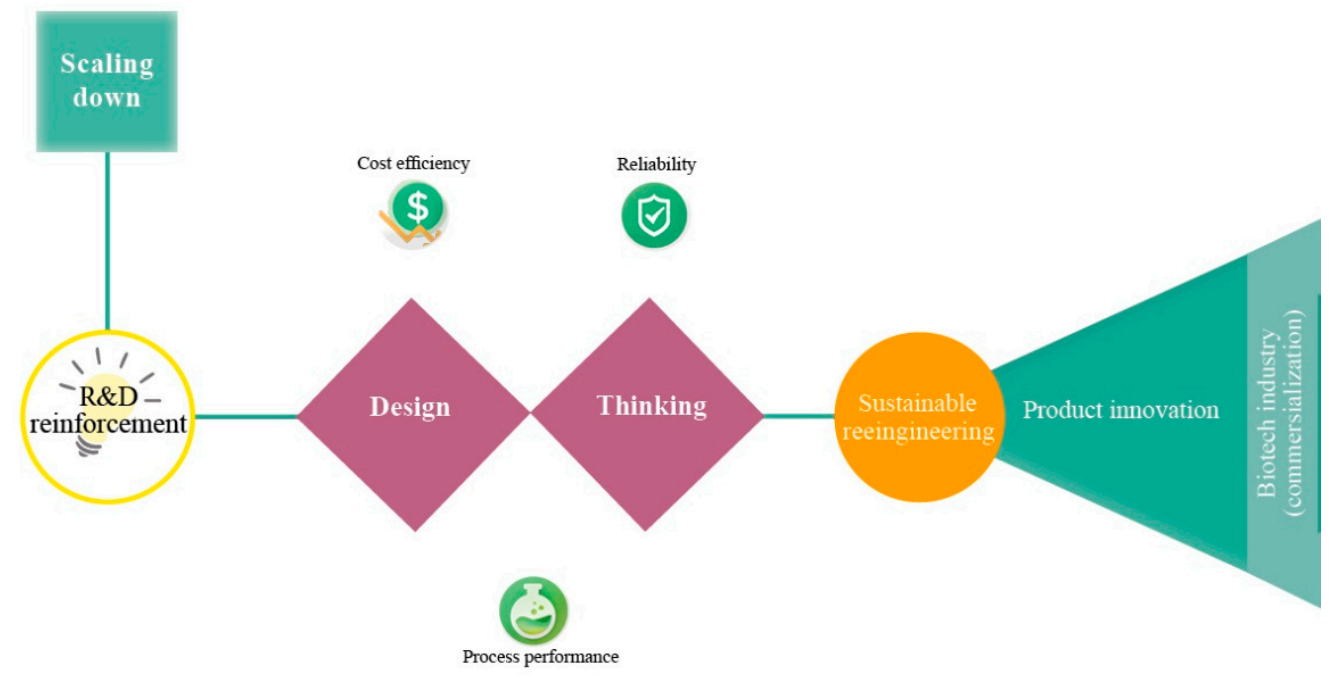

Figure 2. Engineering pathways of the miniaturization concept (top left to right).

Biotech enterprises have to compile current research and frontline developments in bioreactors and make endeavors towards the design and application of sustainable principles though process intensification. 


\subsection{Miniature Bioreactors}

In the case of an anaerobic fermentation process, small anaerobic digesters (AD) can serve as a screening tool for biogas production. A fermentation screening system using low-volume reactors would be able to operate and control many parallel fermenters. Besides, parallelization of a miniature AD system enables the monitoring of multiple operational parameters allowing detailed process insight [17]. Currently, no minimum size of a commercial miniaturized bioreactor system has been established. The operating volume of miniature systems preferably remains less than $20 \mathrm{~mL}$. An overview of the state-of-the-art miniature bioreactor systems and their main characteristics is given in Table 1. The control of miniaturized bioreactor systems remains very complex and lacks research. Due to the necessity of an anoxic environment, the downscaling of anaerobic digesters is more challenging compared to other bioreactors, although mixing becomes less demanding.

Table 1. Miniature bioreactor systems and their main characteristics.

\begin{tabular}{|c|c|c|c|c|c|}
\hline Reactor Volume & Application & Material & Mixing & Sensors & Ref. \\
\hline Milliliter scale tank BR (10 mL) & Mycelium forming & PEEK* & Magnetic & $\mathrm{pH}, \mathrm{DO}$ & {$[26]$} \\
\hline $\begin{array}{c}\text { Milliliter scale BR } \\
(12 \mathrm{~mL})\end{array}$ & $\begin{array}{c}\text { Measuring power } \\
\text { consumption/energy } \\
\text { dissipation }\end{array}$ & & magnetic & $\begin{array}{l}\text { Torque, particle } \\
\text { size }\end{array}$ & {$[27]$} \\
\hline SimcellTM (1 mL) & Cell cultivation & & Sparging & $\mathrm{pH}, \mathrm{DO}$ & [28] \\
\hline $\operatorname{ambrTM}(15 \mathrm{~mL})$ & Cell cultivation & & Sparging & $\mathrm{pH}, \mathrm{DO}$ & [31] \\
\hline ambrTM (15 mL) & Cell cultivation & & Sparging & $\mathrm{pH}, \mathrm{DO}$ & [32] \\
\hline $\begin{array}{l}\text { Mini bioreactor } \\
(30 \mathrm{~mL})\end{array}$ & $\begin{array}{l}\text { Mammalian cell } \\
\text { culturing }\end{array}$ & & $\begin{array}{l}\text { Angled disc } \\
\text { impeller }\end{array}$ & Temperature & [33] \\
\hline $\begin{array}{l}\text { BioREACTOR } 48 \\
\quad(8-15 \mathrm{~mL})\end{array}$ & Parallel fermentation & & $\begin{array}{l}\text { Autoinduction } \\
\text { impeller }\end{array}$ & $\mathrm{pH}, \mathrm{DO}$ & [34] \\
\hline $\begin{array}{c}\text { RoboLector } \\
(800-2400 \mu \mathrm{L})\end{array}$ & Parallel fermentation & & Shaking & $\begin{array}{l}\text { biomass, } \mathrm{pH}, \mathrm{DO}, \\
\text { fluorescence }\end{array}$ & {$[35]$} \\
\hline $\begin{array}{l}\text { micro-Matrix } \\
\quad(10 \mathrm{~mL})\end{array}$ & Parallel fermentation & & Shaking & $\begin{array}{c}\mathrm{pH}, \mathrm{DO}, \\
\text { Temperature }\end{array}$ & {$[36]$} \\
\hline
\end{tabular}

The materials employed for the manufacturing of the bioreactors may influence their applicability (Figure 3). The thermal properties of the material, e.g., thermal conductivity, thermal expansion as well as melting point, are important when the reactor vessel is exposed to high temperatures $\left(121^{\circ} \mathrm{C}\right)$. The chemical properties, such as chemical resistance, are also crucial for the operation procedure. Lastly, the physical properties of surfaces affect the reactor vessel performance as they are related to bacterial adherence and biofilm formation [37]. 


\section{Fabrication materials for microreactors}

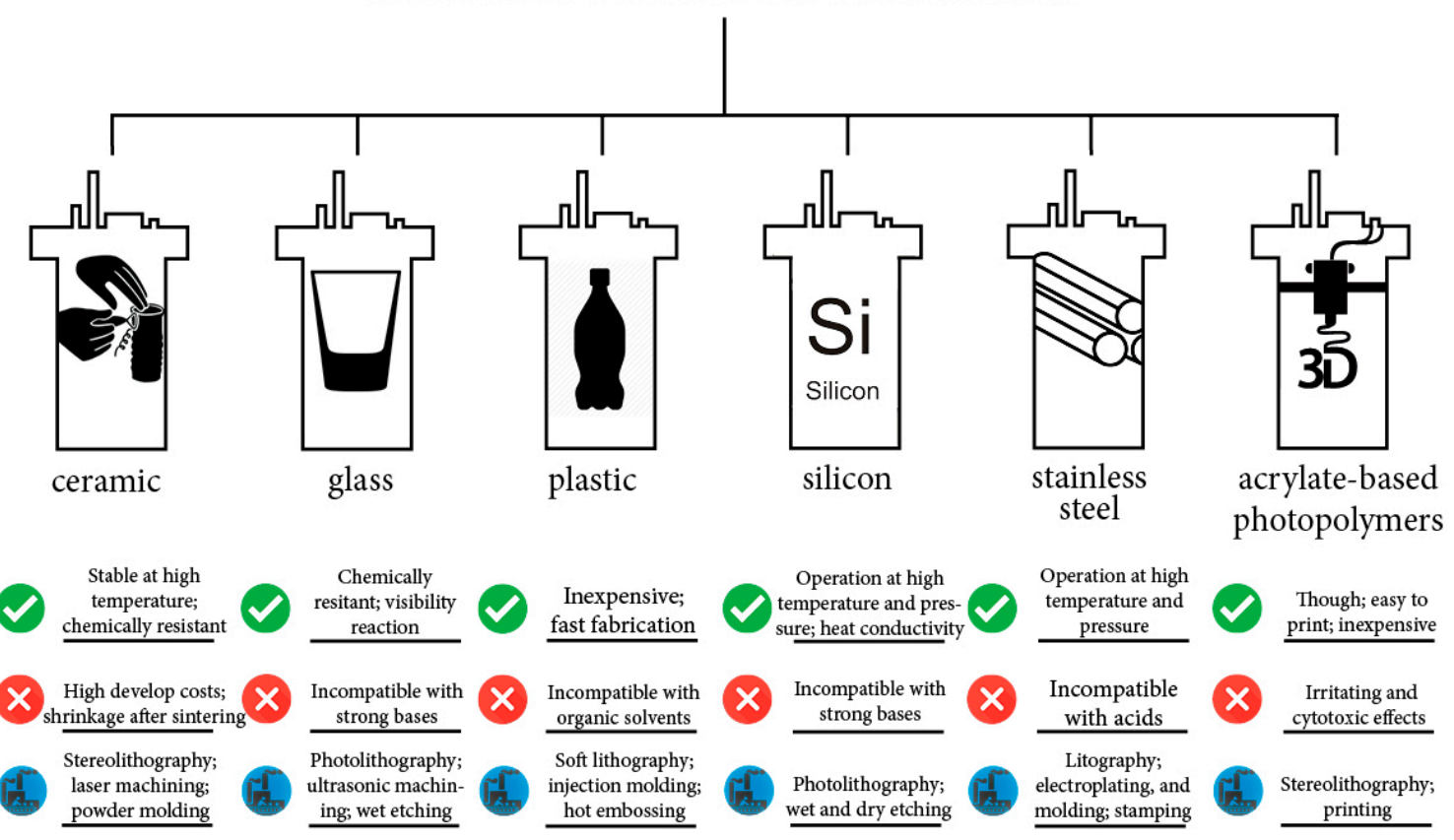

Figure 3. Highlighted features for various miniature reactor fabrication materials [38-48].

A continuous mini-bioreactor system may consist of multiple parts and the reactor vessel is one of those parts. When scaling down the bioreactor, three main aspects must be taken into account. These aspects are maintaining the possibility to sterilize the reactor, maintain perfect mixing and options to measure and control, $\mathrm{pH}$, dissolved oxygen (DO), temperature and level. These three aspects have to be reevaluated when designing a continuous miniature bioreactor. Currently, relatively large and expensive bioreactors are used in the laboratory. If cheaper and smaller bioreactors could replace those bioreactors, while still maintaining the same performance, that would be ideal. A morphological overview is depicted in Table 2 to give an overview of the possible solutions per subfunction. This overview provides a systematic approach to combining solutions and deriving working structures.

Table 2. Morphological overview within the first column, the subfunctions with multiple suitable solutions and in the remaining columns the different solutions.

\begin{tabular}{cccccc}
\hline Solutions & 1 & 3 & 4 & 5 \\
\hline $\begin{array}{c}\text { Supply } \\
\text { thermal } \\
\text { energy }\end{array}$ & Water bath & Water jacket & Hot air oven & Micro heaters & Coil \\
\hline $\begin{array}{c}\text { Supply } \\
\text { electrical } \\
\text { energy }\end{array}$ & Plug and socket & & & \\
\hline
\end{tabular}


Table 2. Cont.

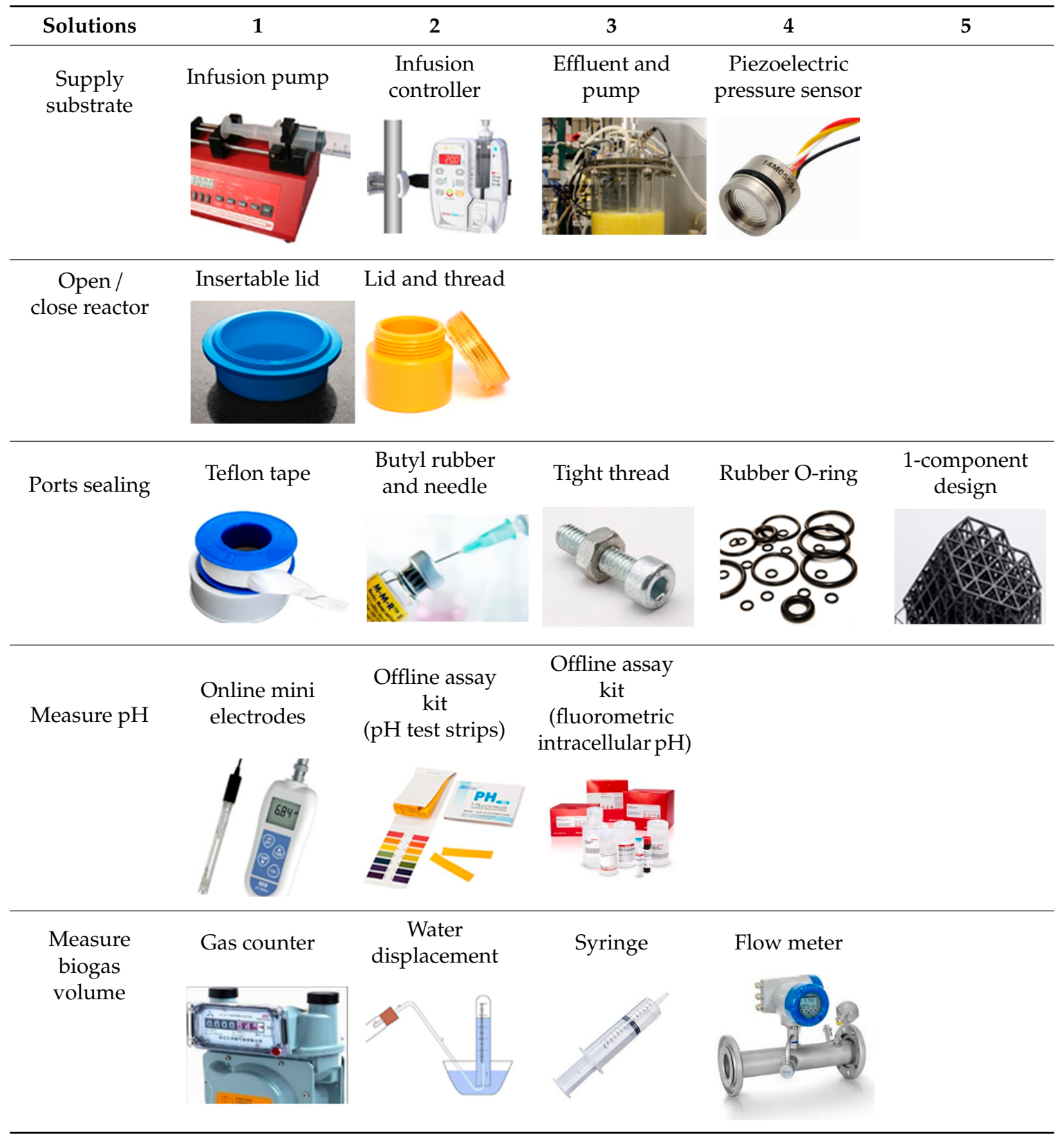

\subsection{Fluid Dynamics}

The flow characteristics in a miniaturized bioreactor differ significantly from those in the laboratory scale reactor $[49,50]$. At the microscale, different forces become dominant over those experienced in everyday life [51]. Because of scaling, it is often counterproductive to simply shrink an existing large device and expect it to function properly at the micro-level [52]. Therefore, new designs must be created to take advantage of forces that work on the microscale. Beebe et al. [49] describe different effects that become dominant in microfluidics, including laminar flow, diffusion, fluidic resistance, surface area to volume ratio, and surface tension. The small dimensions of miniaturized bioreactor systems typically result in laminar fluid flow conditions of the fluid phase [53-56]. A cylindrical reactor design, which is typical for continuously stirred tank reactors (CSTRs), enhances the predictability of the laminar flow dynamics [57]. The rounding of the edges enables the flow to remain laminar and predictable, rather than becoming a random and complicated flow structure of interacting vortices [51]. 
Fluid dynamics have successfully integrated different stirring mechanisms and pumps to achieve homogenous conditions [56,58-61].

\subsection{Parallelization}

Gathering comprehensive process information concerning the development of a bioprocess requires several simultaneous experiments. Therefore, there is a demand for cost-effective, parallel, and multiparametric systems with a high throughput [62]. Parallelization, in bioprocess development, signifies the practice where multiple reactors are employed side by side, thus in parallel [4]. This utilization of multiple reactors in parallel, rather than one reactor, which is used sequentially, increases the experimental throughput. Additionally, the time required for the process development will reduce [2]. By setting the tested parameter differently for each reactor, high experimental throughput is achieved regarding that parameter.

\subsection{Sensor Capabilities}

Online and in real-time monitoring of a bioprocess is inherently complex. However, it ensures the control of the vessel conditions and the optimal use of raw materials. Thus, consistent quality of the final product and a reduction in wastes and process cycle time can be reassured. Besides, the replacement of costly and slow laboratory testing (screening systems) opens up the possibility of bioprocess innovation $[12,63]$. When the bioreactors are scaled down, the sensors are also required to decrease in size, to assure this detailed monitoring of the bioprocess in the miniature bioreactor. A solution is integrating the sensor into small fabricated devices, which is indicated by [23]. Currently, most of these microfabricated devices with integrated sensing capabilities solely monitor just the basic culture conditions, such as temperature, $\mathrm{DO}, \mathrm{pH}$ and optical density [62,64]. Besides sensors that are integrated into miniature bioreactors, other available micro-sensors can be used. Examples are MEMS-based chemical concentration sensors [65], gold-plated microscopic electrode needle arrays [66] and miniaturized gas sensors [67].

\section{Facets of 3D Printing}

\subsection{D Printing-Additive Manufacturing}

The prospect of fabricating objects with the use of 3D printing has seen increased interest in recent years [12]. Although the range of commercial products is still limited, 3D printing has potential when considering design and fabrication. The potential of 3D printers explains the interest of multiple research fields in 3D printing applicability. To date, 3D printing in life sciences is mainly used for medical applications, but it has attracted the interest of researchers [68,69]. Essentially, 3D printing is an additive manufacturing technique, which means that the object is fabricated layer-by-layer rather than through molding or subtractive techniques like milling or turning. The variety of materials used in 3D printing (e.g., plastic, stainless steel, ceramics, glass, paper, photopolymers and even living cells) ensures opportunities for multiple applications [70-74]. These materials are in the form of powders, filament, liquids and sheets as a starting product. Furthermore, there are multiple techniques used in $3 \mathrm{D}$ printing and their advantages and drawbacks are outlined in Figure 4.

It is found that different types of applications require different kinds of materials and various kinds of 3D printing techniques. Fused deposition modeling (FDM) is a method that uses a polymer as the main material and builds parts with a layer-by-layer-technique from the bottom to the top, by heating and extruding a thermoplastic filament [75]. Benefits are low cost and simplicity of the process. However, the results have weak mechanical properties, layer-by-layer appearances, poor surface quality, low speed and a limited number of thermoplastic materials that can be used [76]. Therefore, this type of 3D printing is not suitable for all applications. Stereolithography (SLA) is another form of $3 \mathrm{D}$ printing technology that uses photopolymerization, which is the curing of photo-reactive polymers (resin) by using a visible or ultraviolet laser [75]. A thin layer $(25-100 \mu \mathrm{m})$ of resin between the bottom 
of the resin reservoir and a support is cured by illumination with the laser according to a cross-section of the object that needs to be printed. In the next step, the support lifts the object and new resin will flow underneath the first layer that is cured. The next cross-section of the object is illuminated, and the "drawing" process repeats until the object is printed. The unreacted resin is removed after completing the printing. Drawbacks of this method are that it is relatively slow and more expensive than FDM. However, the results are high-quality parts at a fine resolution [76].

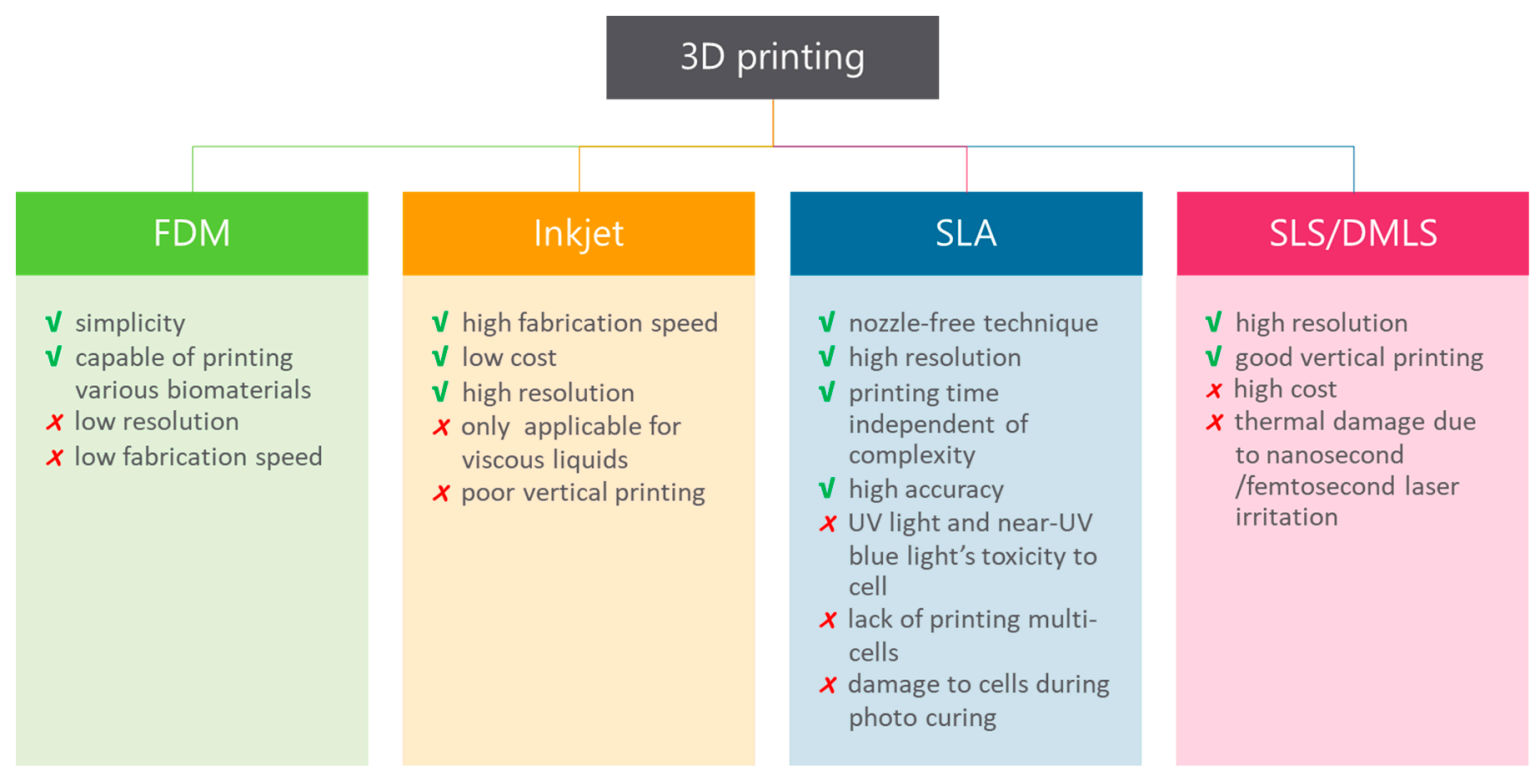

Figure 4. Advantages and limitations of 3D printing techniques. These techniques fabricate an object one layer at a time and include fused deposition modeling (FDM), inkjet bioprinting, stereolithography (SLA), laser sintering (SLS) and direct metal laser sintering (DMLS) [77-83].

Besides the pros and cons, 3D printing in general has some significant advantages over other conventional constructional methods. The process of designing and fabricating an object overtakes some traditional manufacturing steps, including procurement of individual parts, creation of parts using molds, machining to carve parts from blocks of material, welding metal parts together and assembly [12]. Another main advantage of 3D printing is the efficiency in which it uses its material. In other words, 3D printing can not only fabricate internally complex objects that are difficult or impossible to produce by traditional manufacturing techniques, but it can also create these objects with fewer wasted materials [12]. On the other hand, 3D printing has some serious limitations, but some of them have been overcome in the last couple of years. These limitations consist of the relatively slow-building speed, limited object size and detail (resolution), high materials cost and, in some cases, limited object strength (depending on which 3D printing technique) [12].

To show the increasing interest in 3D printing, an overview of the articles found on this subject is given on the Web of Science (Web of science.2020). The search terms were 3D printing, 3D printing + reactor and $3 \mathrm{D}$ printing + materials, and the search was done on the topic of the publications. An overview is given in Table 2. Most notable is the increase in the number of articles on all different search terms. A vast difference appeared between the number of papers found in 2009 and 2019 about $3 \mathrm{D}$ printing.

However, the combination of "3D printing" and "reactor" is still not that common in the scientific literature. Figure 5 shows that there is an increase, but it is yet to be further explored. This means that a lot of research can and will probably be done in this area and also shows the need of this study. 


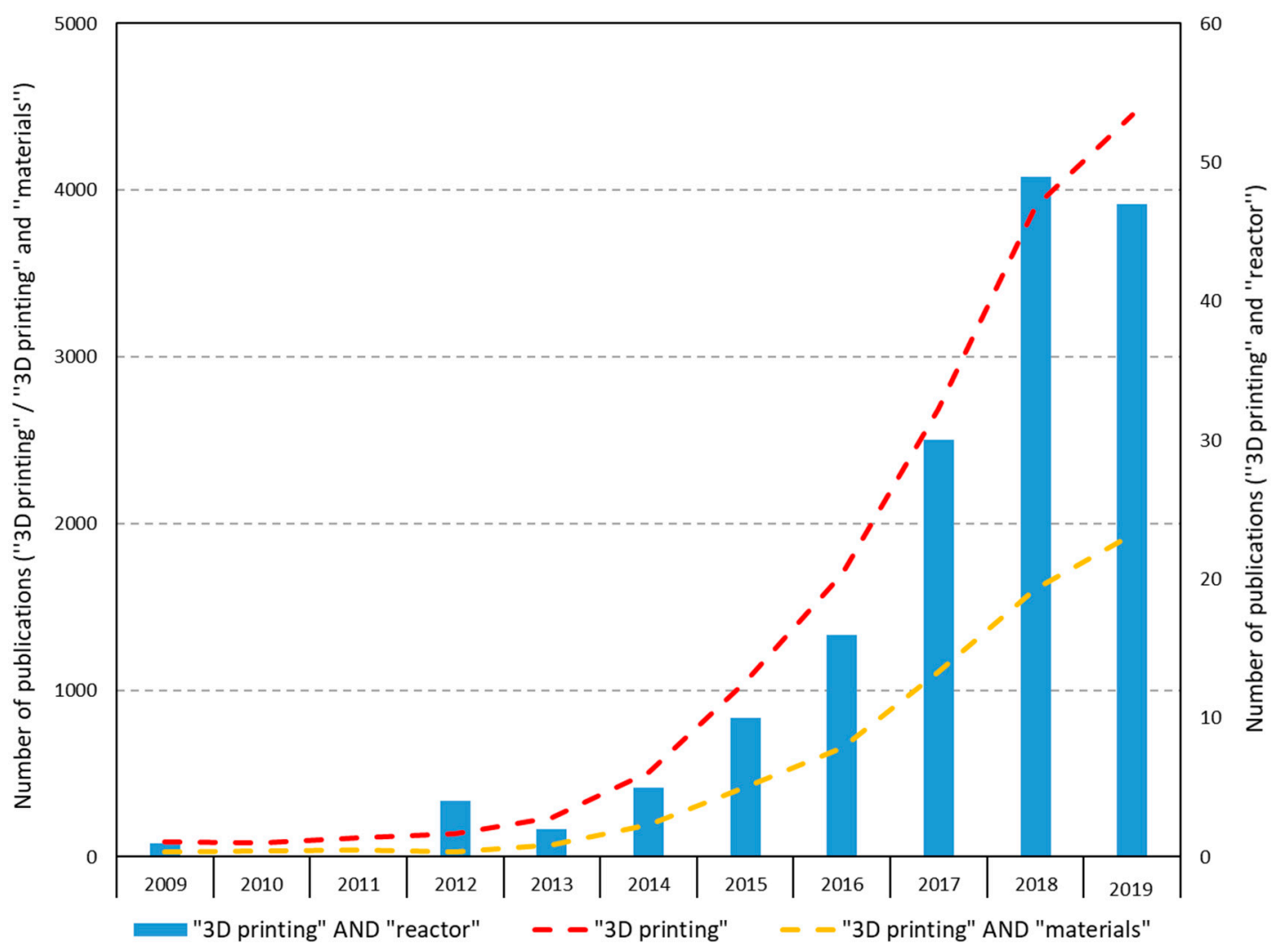

Figure 5. Science citation index publications on 3D printing from the web of science.

\subsection{D Printed Bioreactors}

The volumes of the 3D printed reactors vary widely: some are about $2.65 \mu \mathrm{L}$ for the preparation of perovskite nanocrystals [84], while others are $330 \mathrm{~mL}$ for chromatography [85]. This shows that 3D printing can be applied to many different applications in many different sizes (Table 3). The conditions also range widely between $37^{\circ} \mathrm{C}$ for immobilizing enzymes in hydrogel lattices [86] and an injector temperature of $200{ }^{\circ} \mathrm{C}$ for gas chromatography [85]. Two of the found researches are about bioreactors; one of them is used for mechanical stretching and tissue engineering. The volume of this reactor is $1.35 \mathrm{~mL}$, it is printed with FDM and it is fabricated of acrylonitrile butadiene styrene (ABS). There were no malfunctions during testing [87]. The second bioreactor was also manufactured of ABS and it has a volume of $129.9 \mathrm{~mL}$. The application is maintaining cells and engineered tissue in culture medium and custom grips for mounting 3D engineered tissue constructs and soft tissues. The device is sterilized with 70\% ethanol but can only withstand a maximum failure load of less than 10 Newton [88]. A mixed flow reactor has been 3D printed with SLA using Clear Resin of Formlabs with a volume of $25 \mathrm{~mL}$ [89]. It was used for measuring mineral precipitation rates and can also be modified for use in mineral dissolution experiments. 
Table 3. 3D printed (bio)reactors and their applications.

\begin{tabular}{|c|c|c|c|c|c|c|c|}
\hline Type of Reactor & $\begin{array}{l}\text { 3D Printing } \\
\text { Technique }\end{array}$ & Printing Material & Volume (in $\mathrm{mL}$ ) & Conditions & Application & Remarks & Ref. \\
\hline $\begin{array}{l}\text { Enzyme Reactor } \\
\text { Paper Spray }\end{array}$ & & $\begin{array}{l}\text { Autoclavable polylactic acid } \\
\text { plastic }\end{array}$ & 3.5 & $\begin{array}{l}\text { Heated to } 40^{\circ} \mathrm{C} \text { for } 15 \mathrm{~min} \text {, then } \\
37^{\circ} \mathrm{C} \text { for } 10 \mathrm{~min} \text {. Then a voltage of } \\
4 \mathrm{kV} \text {. Then heated to } 68^{\circ} \mathrm{C} \text { for } 5 \mathrm{~min} \text {. }\end{array}$ & $\begin{array}{c}\text { BuChE detection using a paper } \\
\text { strip coated with } \\
\text { 4-mercaptobutyrylcholine } \\
\text {-functionalized gold nanoparticles }\end{array}$ & $\begin{array}{l}\text { Easy preparation, low-cost, } \\
\text { facile modification. High } \\
\text { reliability and repeatability }\end{array}$ & [90] \\
\hline $\begin{array}{l}\text { Mechanical } \\
\text { Stretching } \\
\text { Bioreactor }\end{array}$ & FDM & $\begin{array}{c}\text { ABS plus-P430 in } \\
\text { combination with SR30 } \\
\text { soluble support material }\end{array}$ & 1.35 & $\begin{array}{l}\text { Procedures of a cell biology/tissue } \\
\text { engineering laboratory. Laminar flow, } \\
\text { mechanical stimulation }\end{array}$ & $\begin{array}{l}\text { Mechanical stretching, } \\
\text { tissue engineering }\end{array}$ & No malfunctions during testing & [87] \\
\hline $\begin{array}{l}\text { Mechanical } \\
\text { bioreactor }\end{array}$ & & $\begin{array}{l}\text { Acrylonitrile butadiene } \\
\text { styrene (ABS) }\end{array}$ & 129.9 & $\begin{array}{l}\text { Cycle tensile strains are applied. } \\
\text { Force and displacement data } \\
\text { collection with ramp control program }\end{array}$ & $\begin{array}{l}\text { Low-cost culture chamber for } \\
\text { maintaining cells and engineered } \\
\text { tissue in culture medium and } \\
\text { custom grips for mounting 3D } \\
\text { engineered tissue constructs and } \\
\text { soft tissues }\end{array}$ & $\begin{array}{l}\text { Can be sterilized with } 70 \% \\
\text { ethanol. Maximum failure } \\
\text { loads of less than } 10 \text { Newton }\end{array}$ & [88] \\
\hline $\begin{array}{l}\text { Continuous flow } \\
\text { reactor }\end{array}$ & SLA & $\begin{array}{l}\text { Methacrylate photopolymer } \\
\text { resin }\end{array}$ & 0.00265 & Stirring at $800 \mathrm{rpm}$ & $\begin{array}{l}\text { Preparation of perovskite } \\
\text { nanocrystals in the } \\
\text { full-emission range }\end{array}$ & & [84] \\
\hline $\begin{array}{l}\text { CuO-nanoparticle } \\
\text { functionalized } \\
\text { flow reactor }\end{array}$ & FDM & Poly(lactic acid) filaments & 0.868 & $\begin{array}{c}\mathrm{pH} 10, \text { reaction temperature }=50^{\circ} \mathrm{C} \\
\text { reaction medium }=100 \mathrm{mM} \\
\text { phosphate-buffered saline }\end{array}$ & $\begin{array}{l}\text { Online fluorometric monitoring } \\
\text { of glucose }\end{array}$ & $\begin{array}{l}\text { The 3D printed flow reactor has } \\
\text { several advantages over the } \\
\text { conventional flow reactor }\end{array}$ & [91] \\
\hline $\begin{array}{l}\text { Hydrogel-based } \\
\text { enzyme reactor }\end{array}$ & $\begin{array}{l}\text { Pneumatic } \\
\text { extrusion-based } \\
\text { printing }\end{array}$ & PEO and Laponite RD & 0.507 & $\begin{array}{c}\mathrm{T}=37^{\circ} \mathrm{C}, \mathrm{pH} 9 . \text { Centrifugation with } \\
10,000 \mathrm{rpm}, 4 \text { min. }\end{array}$ & $\begin{array}{l}\text { Immobilization of enzymes in } \\
\text { hydrogel lattices under } \\
\text { mild conditions }\end{array}$ & Mass transfer limitations occur & [86] \\
\hline $\begin{array}{l}\text { Continuous } \\
\text { reactor }\end{array}$ & FDM & $\begin{array}{l}\text { Acrylonitrile butadiene } \\
\text { styrene (ABS) }\end{array}$ & 0.15 & $\begin{array}{c}\mathrm{T}=60^{\circ} \mathrm{C}, \mathrm{pH} 10 . \text { Agitation at } \\
400 \mathrm{rpm} . \text { Then centrifuged at } \\
5500 \mathrm{rpm} \text { for } 30 \mathrm{~min} .\end{array}$ & $\begin{array}{l}\text { Continuous precipitation of } \\
\text { hydroxyapatite nanoparticles for } \\
\text { potential tissue } \\
\text { engineering applications }\end{array}$ & & [92] \\
\hline $\begin{array}{l}\text { Microfluidic } \\
\text { reactor }\end{array}$ & SLA & $\begin{array}{l}\text { Clear methacrylate-based } \\
\text { resin }\end{array}$ & 1.008 & $\begin{array}{l}\text { Plasma samples added, incubated at } \\
56^{\circ} \mathrm{C} \text { for } 15 \mathrm{~min} .\end{array}$ & $\begin{array}{c}\text { Carrying out extraction, } \\
\text { concentration and isothermal } \\
\text { amplification of nucleic acids in a } \\
\text { variety of body fluids }\end{array}$ & $\begin{array}{l}\text { Cost-effective scalability. } \\
\text { PEG-coating resulted in the best } \\
\text { results. Suitable for all types } \\
\text { of detection }\end{array}$ & [93] \\
\hline $\begin{array}{l}\text { Tubular bent } \\
\text { reactor }\end{array}$ & FDM & Polylactic acid (PLA) & 330 & $\begin{array}{l}\text { Injector } \mathrm{T}=200^{\circ} \mathrm{C} . \text { Gas } \\
\text { chromatography }\end{array}$ & $\begin{array}{l}\text { Redox-initiated continuous } \\
\text { emulsion copolymerization of } \\
\text { styrene-butyl acrylate and vinyl } \\
\text { acetate-neodecanoic acid vinyl ester }\end{array}$ & $\begin{array}{l}\text { Narrow residence time } \\
\text { distribution, small dead } \\
\text { volumes and suitable flow } \\
\text { characteristics for emulsion } \\
\text { copolymerization processes }\end{array}$ & [85] \\
\hline
\end{tabular}


Table 3. Cont.

\begin{tabular}{|c|c|c|c|c|c|c|c|}
\hline Type of Reactor & $\begin{array}{l}\text { 3D Printing } \\
\text { Technique }\end{array}$ & Printing Material & Volume (in $\mathrm{mL}$ ) & Conditions & Application & Remarks & Ref. \\
\hline Mixed flow reactor & SLA & Clear Resin (Formlabs) & 25 & Curing treatment & Measure mineral precipitation rates & $\begin{array}{c}\text { Can also be modified for use in } \\
\text { mineral dissolution } \\
\text { experiments }\end{array}$ & [89] \\
\hline $\begin{array}{l}\text { Miniaturized } \\
\text { polypropylene } \\
\text { reactor }\end{array}$ & FDM & Polypropylene & 0.25 & $\begin{array}{l}\text { Magnetic stirring. Infusion rate of } \\
\qquad 125 \mu \mathrm{L} \mathrm{min}-1\end{array}$ & $\begin{array}{l}\text { Online analysis of a Diels-Alder } \\
\text { reaction and the subsequent retro } \\
\text { Diels-Alder reaction }\end{array}$ & $\begin{array}{l}\text { Resistant to inorganic and } \\
\text { organic reagents and solvents }\end{array}$ & [94] \\
\hline
\end{tabular}




\subsection{Biocompatibility}

Williams [95] states that biocompatibility refers to "the ability of a material to perform with an appropriate host response in a specific situation". However, this definition is argued to be so general and so self-evident that it is not of any real help in advancing knowledge of biocompatibility [96]. Therefore, Williams [97] redefined the definition of biocompatibility as "the ability of a biomaterial to facilitate the most appropriate cellular or tissue response, while performing its desired function concerning a medical therapy, while optimizing the clinically desired performance of the therapy, without drawing out any undesired local or systemic effects in the beneficiary or recipient of the therapy". Black et al. [98] separated the definition of biocompatibility into a host response and a material response. The host response is defined as "the local and systemic response, other than the intended therapeutic response, of living systems to the material", whereas the material response is defined as "the response of the material to living systems" [98]. These definitions imply that biocompatibility phenomena associated with a biomaterial will vary depending on the application, meaning that biocompatibility is not a property of material but a biomaterial-host system [97]. Based on the generic biocompatibility pathways described by Williams (2014) [99], three main biocompatibility goals are defined as "defensive", "target" and "interfering".

For this particular research, biocompatibility is described by translating the three goals into specific requirements: (1) the material surface area of the bioreactor has to be inert; (2) must be non-biodegradable; and (3) bacteria must not adhere to the material. All three requirements are important for research reproducibility and research integrity and these requirements should be accurately tested and at all times kept in mind when doing microbial experiments.

In the microbial research, upcoming 3D printing techniques show opportunities for biomaterials to fabricate miniature bioreactors. The interactions between microbes and biomaterial influence the functionality of the bioreactors in terms of microbial growth. For the majority, this description can be related to the definition of biocompatibility. Instead of having a local host in the system, the system contains an inoculum or medium in which the microbes interact with the material substrate surface. Now the question remains, is the general definition of biocompatibility limited to the medical point of view and should the definition be overhauled or rephrased, or should another term be used to describe the interactions that happen in microbial research?

\subsection{Evaluation of Fabrication Techniques}

Pahl and Beitz (2007) [100] distinguished two main types of criteria, namely, technical and economic criteria. Both criteria consist of multiple aspects that can be modified to the product or process under consideration. In general, the majority of the conventional bioreactors are fabricated using glass, plastic or metal (Eppendorf, 2018). The most generic and applicable manufacturing techniques concerning these materials are injection molding, casting and milling and turning [101]. The technical criteria cover the performance of the process to the final desired product. The overall quality and lifespan are, therefore, included in the technical criteria aspects. Additionally, it is relevant to how complex and accurate the process is. Thus, how complicated the overall process of producing the product is and how detailed the product can be produced. Lastly, the maximum object size can be included as a technical criteria aspect. Currently, the 3D printers entail a limited object size that can be produced. This should also be considered when evaluating the technical performance.

The economic criteria firstly consider the costs. The costs can be separated into raw material costs, production costs and general overhead costs [102]. Additionally, the time required to produce one product is considered. Lastly, the flexibility of the production process entails is considered in the economic criteria aspects. The information for the fabrication process can be obtained using 3D-printing software (e.g., Formlabs, 3D-simplify or Ultimaker Cura). The software calculates the resources and time required per component. Table 4 shows indicative technical and economic criteria that have to be considered for the selection of a reactor fabrication technique. 
Table 4. Indicative technical and economic criteria for manufacturing technique of reactors [101,103-106].

\begin{tabular}{ccc}
\hline Technique & Technical & Economical \\
\hline 3D printing & Quality & Raw material costs \\
Injection molding & Lifespan & Production costs \\
Casting & Process complexity & Production time \\
Milling and turning & Process accuracy & Flexibility \\
& Quality & General overhead costs \\
\hline
\end{tabular}

\section{Conclusions}

In this paper, we discussed several important topics on scaling-down and manufacturing of bioreactors. We brought up issues for combining miniaturization and additive manufacturing techniques, culminating in 3D printing, and how this combination can affect the evolution of biotechnology through the fabrication of advanced screening systems. These topics include the future of the 3D printing application in bioprocess technology, potential for bioreactor miniaturization and concurrent development of bioreactor screening systems for optimization studies. These topics are essential for academics, entrepreneurs and policy makers to be aware of and consider as we usher in a new bioprocess renaissance.

Author Contributions: Conceptualization and methodology, S.A.; writing—original draft preparation, S.A. and J.-I.H.; writing-review and editing, J.K. and G.J.W.E. All authors have read and agreed to the published version of the manuscript.

Funding: This research received no external funding.

Conflicts of Interest: The authors declare no conflict of interest.

\section{References}

1. Bareither, R.; Pollard, D. A review of advanced small-scale parallel bioreactor technology for accelerated process development: Current state and future need. Biotechnol. Prog. 2010, 27, 2-14. [CrossRef] [PubMed]

2. Kurzrock, T.; Kress, K. Downscale Upscale-Elasticity of Scales-An Approach to Forecast Future Requirements in Biotechnology. JSM Biotechnol. Biomed. Eng. 2014, 2, 1030.

3. Li, F.; Hashimura, Y.; Pendleton, R.; Harms, J.; Collins, E.; Lee, B. A Systematic Approach for Scale-Down Model Development and Characterization of Commercial Cell Culture Processes. Biotechnol. Prog. 2006, 22, 696-703. [CrossRef] [PubMed]

4. Powell, J. Reactor Scale-down for Pilot Plant, Bench Scale, and Multi-Throughput Units. In Proceedings of the 2006 Annual Meeting, St Lucia, Australia, 12-18 August 2006.

5. Van't Riet, K.; Tramper, J. Basic Bioreactor Design; CRC Press: Wageningen, The Netherlands, 1911.

6. Bouallagui, H.; Touhami, Y.; Cheikh, R.B.; Hamdi, M. Bioreactor performance in anaerobic digestion of fruit and vegetable wastes. Process Biochem. 2005, 40,989-995. [CrossRef]

7. DeSilva, D.; Urbain, V.; Abeysinghe, D.; Rittmann, B. Advanced analysis of membrane-bioreactor performance with aerobic-anoxic cycling. Water Sci. Technol. 1998, 38, 505-512. [CrossRef]

8. Lübbert, A.; Jørgensen, S. Bioreactor performance: A more scientific approach for practice. J. Biotechnol. 2001, 85, 187-212. [CrossRef]

9. Doran, P.M. Bioprocess Engineering Principles; Academic Press: Cambridge, MA, USA, 1995.

10. Klöckner, W.; Büchs, J. Advances in shaking technologies. Trends Biotechnol. 2012, 30, 307-314. [CrossRef]

11. Merchuk, J.; Contreras, A.; García-Camacho, F.; Molina, E. Studies of mixing in a concentric tube airlift bioreactor with different spargers. Chem. Eng. Sci. 1998, 53, 709-719. [CrossRef]

12. Manyika, J.; Chui, M.; Bughin, J.; Dobbs, R.; Bisson, P.; Marrs, A. Disruptive Technologies: Advances that Will Transform Life, Business, and the Global Economy; McKinsey Global Institute: San Francisco, CA, USA, 2013; Volume 180.

13. Berman, B. 3-D printing: The new industrial revolution. Bus. Horizons 2012, 55, 155-162. [CrossRef]

14. Lattermann, C.; Büchs, J. Design and Operation of Microbioreactor Systems for Screening and Process Development; Bioreactors: Design, Operation and Novel Applications; Wiley: Hoboken, NJ, USA, 2016. 
15. Velez-Suberbie, M.L.; Betts, J.P.J.; Walker, K.L.; Robinson, C.; Zoro, B.; Keshavarz-Moore, E. High throughput automated microbial bioreactor system used for clone selection and rapid scale-down process optimization. Biotechnol. Prog. 2017, 34, 58-68. [CrossRef]

16. Bartlett, D.H. Pressure effects on in vivo microbial processes. Biochim. Biophys. Acta (BBA) Bioenergy 2002, 1595, 367-381. [CrossRef]

17. Hemmerich, J.; Noack, S.; Wiechert, W.; Oldiges, M. Microbioreactor Systems for Accelerated Bioprocess Development. Biotechnol. J. 2018, 13, 1700141. [CrossRef] [PubMed]

18. Nienow, A.W.; Rielly, C.D.; Brosnan, K.; Bargh, N.; Lee, K.; Coopman, K.; Hewitt, C.J. The physical characterisation of a microscale parallel bioreactor platform with an industrial $\mathrm{CHO}$ cell line expressing an IgG4. Biochem. Eng. J. 2013, 76, 25-36. [CrossRef]

19. Bareither, R.; Bargh, N.; Oakeshott, R.; Watts, K.; Pollard, D. Automated disposable small scale reactor for high throughput bioprocess development: A proof of concept study. Biotechnol. Bioeng. 2013, 110, 3126-3138. [CrossRef] [PubMed]

20. Betts, J.I.; Doig, S.D.; Baganz, F. Characterization and Application of a Miniature $10 \mathrm{~mL}$ Stirred-Tank Bioreactor, Showing Scale-Down Equivalence with a Conventional 7 L Reactor. Biotechnol. Prog. 2006, 22, 681-688. [CrossRef]

21. Betts, J.I.; Baganz, F. Miniature bioreactors: Current practices and future opportunities. Microb. Cell Factories 2006, 5, 21. [CrossRef]

22. Watts, P.; Wiles, C. Micro reactors: A new tool for the synthetic chemist. Org. Biomol. Chem. 2007, 5, 727. [CrossRef]

23. Szita, N.; Boccazzi, P.; Zhang, Z.; Boyle, P.; Sinskey, A.J.; Jensen, K.F. Development of a multiplexed microbioreactor system for high-throughput bioprocessing. Lab Chip 2005, 5, 819-826. [CrossRef]

24. Lee, H.L.T.; Boccazzi, P.; Ram, R.J.; Sinskey, A.J. Microbioreactor arrays with integrated mixers and fluid injectors for high-throughput experimentation with $\mathrm{pH}$ and dissolved oxygen control. Lab Chip 2006, 6, 1229. [CrossRef]

25. Maharbiz, M.M.; Holtz, W.J.; Howe, R.T.; Keasling, J.D. Microbioreactor arrays with parametric control for high-throughput experimentation. Biotechnol. Bioeng. 2004, 85, 376-381. [CrossRef]

26. Hortsch, R.; Stratmann, A.; Weuster-Botz, D. New milliliter-scale stirred tank bioreactors for the cultivation of mycelium forming microorganisms. Biotechnol. Bioeng. 2010, 106, 443-451. [CrossRef]

27. Hortsch, R.; Weuster-Botz, D. Power consumption and maximum energy dissipation in a milliliter-scale bioreactor. Biotechnol. Prog. 2009, 26, 599. [CrossRef] [PubMed]

28. Amanullah, A.; Otero, J.M.; Mikola, M.; Hsu, A.; Zhang, J.; Aunins, J.; Schreyer, H.B.; Hope, J.A.; Russo, A.P. Novel micro-bioreactor high throughput technology for cell culture process development: Reproducibility and scalability assessment of fed-batch CHO cultures. Biotechnol. Bioeng. 2010, 106, 57-67. [CrossRef] [PubMed]

29. Figallo, E.; Cannizzaro, C.; Gerecht, S.; Burdick, J.A.; Langer, R.; Elvassore, N.; Vunjak-Novakovic, G. Micro-bioreactor array for controlling cellular microenvironments. Lab Chip 2007, 7, 710-719. [CrossRef] [PubMed]

30. Cimetta, E.; Figallo, E.; Cannizzaro, C.; Elvassore, N.; Vunjak-Novakovic, G. Micro-bioreactor arrays for controlling cellular environments: Design principles for human embryonic stem cell applications. Methods 2009, 47, 81-89. [CrossRef]

31. Janakiraman, V.; Kwiatkowski, C.; Kshirsagar, R.; Ryll, T.; Huang, Y. Application of High-Throughput Mini-Bioreactor System for Systematic Scale-Down Modeling, Process Characterization and Control Strategy Development. Biotechnol. Prog. 2015, 31, 1623-1632. [CrossRef]

32. Delouvroy, F.; Siriez, G.; Tran, A.-V.; Mukankurayija, L.; Kochanowski, N.; Malphettes, L. ambr ${ }^{\mathrm{TM}}$ Mini-bioreactor as a high-throughput tool for culture process development to accelerate transfer to stainless steel manufacturing scale: Comparability study from process performance to product quality attributes. BMC Proc. 2015, 9, P78. [CrossRef]

33. Bulnes-Abundis, D.; Carrillo-Cocom, L.M.; Aráiz-Hernández, D.; García-Ulloa, A.; Granados-Pastor, M.; Sánchez-Arreola, P.B.; Murugappan, G.; Alvarez, M.M. A simple eccentric stirred tank mini-bioreactor: Mixing characterization and mammalian cell culture experiments. Biotechnol. Bioeng. 2012, 110, 1106-1118. [CrossRef] 
34. Nickel, D.B.; Bournazou, M.N.C.; Wilms, T.; Neubauer, P.; Knepper, A. Online bioprocess data generation, analysis, and optimization for parallel fed-batch fermentations in milliliter scale. Eng. Life Sci. 2016, 17, 1195-1201. [CrossRef]

35. Available online: https://www.m2p-labs.com/bioreactors/products/biolector-pro/\#!/1 (accessed on 17 February 2020).

36. Available online: https://www.applikon-biotechnology.com/en/products/cultivation-systems/micro-matrix/ (accessed on 4 March 2020).

37. Katsikogianni, M.G.; Missirlis, Y.F. Concise review of mechanisms of bacterial adhesion to biomaterials and of techniques used in estimating bacteria-material interactions. Eur. Cell Mater. 2004, 8, 37-57. [CrossRef]

38. Knitter, R.; Liauw, M.A. Ceramic microreactors for heterogeneously catalysed gas-phase reactions. Lab Chip 2004, 4, 378-383. [CrossRef] [PubMed]

39. Jain, K.; Wu, C.; Atre, S.V.; Jovanovic, G.; Narayanan, V.; Kimura, S.; Sprenkle, V.; Canfield, N.; Roy, S. Synthesis of Nanoparticles in High Temperature Ceramic Microreactors: Design, Fabrication and Testing. Int. J. Appl. Ceram. Technol. 2009, 6, 410-419. [CrossRef]

40. Woolley, A.T.; Mathies, R.A. Ultra-high-speed DNA fragment separations using microfabricated capillary array electrophoresis chips. Proc. Natl. Acad. Sci. USA 1994, 91, 11348-11352. [CrossRef] [PubMed]

41. Mellors, J.S.; Gorbounov, V.; Ramsey, R.S.; Ramsey, J.M. Fully Integrated Glass Microfluidic Device for Performing High-Efficiency Capillary Electrophoresis and Electrospray Ionization Mass Spectrometry. Anal. Chem. 2008, 80, 6881-6887. [CrossRef] [PubMed]

42. Bens, A.; Seitz, H.; Bermes, G.; Emons, M.; Pansky, A.; Roitzheim, B.; Tobiasch, E.; Tille, C. Non-toxic flexible photopolymers for medical stereolithography technology. Rapid Prototyp. J. 2007, 13, 38-47. [CrossRef]

43. Becker, H.; Gärtner, C. Polymer based micro-reactors. Rev. Mol. Biotechnol. 2001, 82, 89-99. [CrossRef]

44. Becker, H.; Gartner, C. Polymer micro fabrication methods for micro fluidicanalytical applications. Electrophoresis 2000, 21, 12-26. [CrossRef]

45. Geyer, K.; Seeberger Peter, H. Optimization of glycosylation reactions in a microreactor. Helv. Chim. Acta 2007, 90, 395-403. [CrossRef]

46. Yen, B.; Gunther, A.; Thalmann, M.; Bawendi, M.; Jensen, K. A microfabricated segmented-flow reactor for the synthesis of CdSe quantum dots. In Proceedings of the Eighth International Conference on Miniaturized Systems in Chemistry and Life Science, Malmö, Sweden, 26-30 September 2004.

47. Hessel, V.; Hardt, S.; Lowe, H. Chemical Micro Process Engineering: Fundamentals, Modelling and Reactions; John Wiley \& Sons: Hoboken, NJ, USA, 2004; p. 712.

48. Ehrfeld, W.; Hessel, V.; Lowe, H. Microreactors: New Technology for Modern Chemistry; Wiley/VCH: Weinheim, Germany, 2000; p. 288.

49. Beebe, D.J.; Mensing, G.A.; Walker, G.M. Physics and Applications of Microfluidics in Biology. Annu. Rev. Biomed. Eng. 2002, 4, 261-286. [CrossRef]

50. Tehranirokh, M.; Kouzani, A.Z.; Francis, P.S.; Kanwar, J.R. Microfluidic devices for cell cultivation and proliferation. Biomicrofluidics 2013, 7, 051502. [CrossRef]

51. Brody, J.P.; Yager, P.; Goldstein, R.E.; Austin, R. Biotechnology at low Reynolds numbers. Biophys. J. 1996, 71, 3430-3441. [CrossRef]

52. Purcell, E.M. Life at low Reynolds number. Am. J. Phys. 1977, 45, 3. [CrossRef]

53. Breslauer, D.N.; Lee, P.J.; Lee, L.P. Microfluidics-based systems biology. Mol. BioSyst. 2006, 2, 97. [CrossRef] [PubMed]

54. Wu, M.-H.; Huang, S.-B.; Lee, G.-B. Microfluidic cell culture systems for drug research. Lab Chip 2010, 10, 939. [CrossRef]

55. Alam, M.N.H.Z.; Gernaey, K.V. Overview on Design Considerations for Development of Disposable Microbioreactor Prototypes. J. Teknol. 2012, 59. [CrossRef]

56. Dietzel, A. Microsystems for Pharmatechnology: Manipulation of Fluids, Particles, Droplets and Cells; Springer: Braunschweig, Germany, 2016.

57. Tabatabaei, M.; Ghanavati, H. Biogas: Fundamentals, Process, and Operation, 6th ed.; Springer: Cham, Switzerland, 2018.

58. Schäpper, D.; Stocks, S.M.; Szita, N.; Lantz, A.E.; Gernaey, K.V. Development of a single-use microbioreactor for cultivation of microorganisms. Chem. Eng. J. 2010, 160, 891-898. [CrossRef]

59. Zhang, Z.; Boccazzi, P.; Choi, H.-G.; Perozziello, G.; Sinskey, A.J.; Jensen, K.F. Microchemostat-Microbial continuous culture in a polymer-based, instrumented microbioreactor. Lab Chip 2006, 6, 906-913. [CrossRef] 
60. Lee, K.S.; Boccazzi, P.; Sinskey, A.J.; Ram, R.J. Microfluidic chemostat and turbidostat with flow rate, oxygen, and temperature control for dynamic continuous culture. Lab Chip 2011, 11, 1730. [CrossRef]

61. Park, J.; Wu, J.; Polymenis, M.; Han, A. Microchemostat array with small-volume fraction replenishment for steady-state microbial culture. Lab Chip 2013, 13, 4217. [CrossRef]

62. Zanzotto, A.; Szita, N.; Boccazzi, P.; Lessard, P.; Sinskey, A.J.; Jensen, K.F. Membrane-aerated microbioreactor for high-throughput bioprocessing. Biotechnol. Bioeng. 2004, 87, 243-254. [CrossRef]

63. Larroche, C.; Sanroman, M.; Du, G.; Pandey, A. Current Developments in Biotechnology and Bioengineering: Bioprocesses, Bioreactors and Controls; Elsevier: Amsterdam, The Netherlands, 2016.

64. Bower, D.M.; Lee, K.S.; Ram, R.J.; Prather, K.L. Fed-batch microbioreactor platform for scale down and analysis of a plasmid DNA production process. Biotechnol. Bioeng. 2012, 109, 1976-1986. [CrossRef] [PubMed]

65. Sparks, D.; Kawaguchi, K.; Yasuda, M.; Riley, D.; Cruz, V.B.; Tran, N.; Chimbayo, A.; Najafi, N. Embedded MEMS-based concentration sensor for fuel cell and biofuel applications. Sens. Actuators Phys. 2008, 145, 9-13. [CrossRef]

66. Harper, J.C.; Brozik, S.M.; Flemming, J.H.; McClain, J.L.; Polsky, R.; Raj, D.; Eyck, G.A.T.; Wheeler, D.R.; Achyuthan, K.E. Fabrication and Testing of a Microneedles Sensor Array for p-Cresol Detection with Potential Biofuel Applications. ACS Appl. Mater. Interfaces 2009, 1, 1591-1598. [CrossRef]

67. Sharma, S.; Madou, M. A new approach to gas sensing with nanotechnology. Philos. Trans. R. Soc. Math. Phys. Eng. Sci. 2012, 370, 2448-2473. [CrossRef]

68. Ventola, C.L. Medical Applications for 3D Printing: Current and Projected Uses. P T A Peer Rev. J. Formul. Manag. 2014, 39, 704-711.

69. Bhattacharjee, N.; Urrios, A.; Kang, S.; Folch, A. The upcoming 3d-printing revolution in microfluidics. Lab Chip 2016, 16, 1720-1742. [CrossRef] [PubMed]

70. Chae, M.P.; Rozen, W.M.; McMenamin, P.G.; Findlay, M.W.; Spychal, R.T.; Hunter-Smith, D.J. Emerging Applications of Bedside 3D Printing in Plastic Surgery. Front. Surg. 2015, 2. [CrossRef] [PubMed]

71. Ambrosi, A.; Pumera, M. 3D-printing technologies for electrochemical applications. Chem. Soc. Rev. 2016, 45, 2740-2755. [CrossRef] [PubMed]

72. Kotz, F.; Arnold, K.; Bauer, W.; Schild, D.; Keller, N.; Sachsenheimer, K.; Nargang, T.M.; Richter, C.; Helmer, D.; Rapp, B.E. Three-dimensional printing of transparent fused silica glass. Nature 2017, 544, 337-339. [CrossRef] [PubMed]

73. Selimis, A.; Mironov, V.; Farsari, M. Direct laser writing: Principles and materials for scaffold 3D printing. Microelectron. Eng. 2015, 132, 83-89. [CrossRef]

74. Murphy, S.V.; Atala, A. 3D bioprinting of tissues and organs. Nat. Biotechnol. 2014, 32, 773-785. [CrossRef]

75. Shahrubudin, N.; Lee, T.; Ramlan, R. An Overview on 3D Printing Technology: Technological, Materials, and Applications. Procedia Manuf. 2019, 35, 1286-1296. [CrossRef]

76. Ngo, T.; Kashani, A.; Imbalzano, G.; Nguyen, Q.; Hui, D. Additive manufacturing (3D printing): A review of materials, methods, applications and challenges. Compos. Part B Eng. 2018, 143, 172-196. [CrossRef]

77. Olakanmi, E.O.T.; Cochrane, R.; Dalgarno, K. A review on selective laser sin-tering/melting (sls/slm) of aluminium alloy powders: Processing, microstructure, and properties. Prog. Mater. Sci. 2015, 74, 401-477. [CrossRef]

78. Yan, C.; Hao, L.; Hussein, A.; Young, P.; Huang, J.; Zhu, W. Microstructure and mechanical properties of aluminium alloy cellular lattice structures manufactured by direct metal laser sintering. Mater. Sci. Eng. A 2015, 628, 238-246. [CrossRef]

79. Ning, F.; Cong, W.; Qiu, J.; Wei, J.; Wang, S. Additive manufacturing of carbon fiber reinforced thermoplastic composites using fused deposition modeling. Compos. Part B Eng. 2015, 80, 369-378. [CrossRef]

80. Au, A.K.; Lee, W.; Folch, A. Mail-order microfluidics: Evaluation of stereolithography for the production of microfluidic devices. Lab Chip 2014, 14, 1294-1301. [CrossRef]

81. Liu, S.; Ye, F.; Liu, L.; Liu, Q. Feasibility of preparing of silicon nitride ceramics components by aqueous tape casting in combination with laminated object manufacturing. Mater. Des. 2015, 66, 331-335. [CrossRef]

82. Zhang, X.; Zhang, Y. Tissue engineering applications of three-dimensional bioprint-ing. Cell Biochem. Biophys. 2015, 72, 777-782. [CrossRef]

83. Derakhshanfar, S.; Mbeleck, R.; Xu, K.; Zhang, X.; Zhong, W.; Xing, M. 3d bio-printing for biomedical devices and tissue engineering: A review of recent trends and advances. Bioact. Mater. 2018, 3, 144-156. [CrossRef] 
84. Li, C.; Ding, B.; Zhang, L.; Song, K.; Tao, S. 3D-printed continuous flow reactor for high yield synthesis of CH3NH3PbX3 (X = Br, I) nanocrystals. J. Mater. Chem. C 2019, 7, 9167-9174. [CrossRef]

85. Bettermann, S.; Schroeter, B.; Moritz, H.-U.; Pauer, W.; Fassbender, M.; Luinstra, G.A. Continuous emulsion copolymerization processes at mild conditions in a 3D-printed tubular bended reactor. Chem. Eng. J. 2018, 338, 311-322. [CrossRef]

86. Schmieg, B.; Döbber, J.; Kirschhöfer, F.; Pohl, M.; Franzreb, M. Advantages of Hydrogel-Based 3D-Printed Enzyme Reactors and Their Limitations for Biocatalysis. Front. Bioeng. Biotechnol. 2019, 6, 211. [CrossRef] [PubMed]

87. Davis, J. Animal Cell Culture: Essential Methods. Chichester, West Sussex. 2011. Available online: http://search.ebscohost.com.proxy-ub.rug.nl/login.aspx?direct=true\&db=nlebk\&AN=391253\&site= ehost-live\&scope $=$ site (accessed on 9 December 2019).

88. Raveling, A.R.; Theodossiou, S.K.; Schiele, N.R. A 3D printed mechanical bioreactor for investigating mechanobiology and soft tissue mechanics. MethodsX 2018, 5, 924-932. [CrossRef] [PubMed]

89. Michel, F.M.; Rimstidt, J.D.; Kletetschka, K. 3D printed mixed flow reactor for geochemical rate measurements. Appl. Geochem. 2018, 89, 86-91. [CrossRef]

90. Yang, Y.; Liu, H.; Chen, Z.; Wu, T.; Jiang, Z.; Tong, L.; Tang, B. A Simple 3D-Printed Enzyme Reactor Paper Spray Mass Spectrometry Platform for Detecting BuChE Activity in Human Serum. Anal. Chem. 2019, 91, 12874-12881. [CrossRef]

91. Su, C.-K.; Tseng, H.-H. 3D-printed CuO nanoparticle-functionalized flow reactor enables online fluorometric monitoring of glucose. Microchim. Acta 2019, 186, 404. [CrossRef]

92. Latocha, J.; Wojasiński, M.; Jurczak, K.; Gierlotka, S.; Sobieszuk, P.; Ciach, T.; Jurczak, K. Precipitation of hydroxyapatite nanoparticles in 3D-printed reactors. Chem. Eng. Process. Process. Intensif. 2018, 133, 221-233. [CrossRef]

93. Kadimisetty, K.; Song, J.; Doto, A.M.; Hwang, Y.; Peng, J.; Mauk, M.G.; Bushman, F.D.; Gross, R.; Jarvis, J.N.; Liu, C. Fully 3D printed integrated reactor array for point-of-care molecular diagnostics. Biosens. Bioelectron. 2018, 109, 156-163. [CrossRef]

94. Scotti, G.; Nilsson, S.M.E.; Haapala, M.; Pöhö, P.; Gennäs, G.B.A.; Yli-Kauhaluoma, J.; Kotiaho, T. A miniaturised 3D printed polypropylene reactor for online reaction analysis by mass spectrometry. React. Chem. Eng. 2017, 2, 299-303. [CrossRef]

95. Williams, D.F. On the mechanisms of biocompatibility. Biomaterials 2008, 29, 2941-2953. [CrossRef]

96. Ai, H.; Anderson, J.; Anseth, K.; Antoniac, I.; Barbosa, M.; Basu, B.; Best, S.; Bettini, R.; Bezuidenhout, D.; Bizios, R.; et al. Attendees at Chengdu Definitions in Biomaterials Conference 2019. In Proceedings of the Definitions of Biomaterials for the Twenty-First Century, Chester, UK, 3-5 March 1986; Elsevier: Amsterdam, The Netherlands, 2019.

97. Williams, D.F. Biocompatibility Pathways in Tissue-Engineering Templates. Engineering 2018, 4, $286-290$. [CrossRef]

98. Black, J. Biological Performance of Materials; Informa UK Limited: Essex, UK, 2005.

99. Williams, D.F. There is no such thing as a biocompatible material. Biomaterials 2014, 35, 10009-10014. [CrossRef] [PubMed]

100. Pahl, G.; Beitz, W. Engineering Design: A Systematic Approach, 3rd ed.; Springer: London, UK, 2007.

101. Kalpakjian, S. Manufacturing Processes for Engineering Materials, 5th ed.; Pearson Education: London, UK, 2008.

102. Edmonds, T.; Edmonds, C.; Tsay, B.; Olds, P. Fundamental Managerial Accounting Concepts, 8th ed.; McGraw-Hill Education: New York, NY, USA, 2016.

103. Heinzel, A.; Mahlendorf, F.; Niemzig, O.; Kreuz, C. Injection moulded low cost bipolar plates for PEM fuel cells. J. Power Sources 2004, 131, 35-40. [CrossRef]

104. Chougule, R.G.; Ravi, B. Casting cost estimation in an integrated product and process design environment. Int. J. Comput. Integr. Manuf. 2006, 19, 676-688. [CrossRef]

105. Shunmugam, M.; Reddy, S.B.; Narendran, T. Selection of optimal conditions in multi-pass face-milling using a genetic algorithm. Int. J. Mach. Tools Manuf. 2000, 40, 401-414. [CrossRef]

106. Hui, Y.V.; Leung, L.C.; Linn, R. Optimal machining conditions with costs of quality and tool maintenance for turning. Int. J. Prod. Res. 2001, 39, 647-665. [CrossRef]

(C) 2020 by the authors. Licensee MDPI, Basel, Switzerland. This article is an open access article distributed under the terms and conditions of the Creative Commons Attribution (CC BY) license (http://creativecommons.org/licenses/by/4.0/). 